\title{
Chryseobacterium shigense sp. nov., a yellow-pigmented, aerobic bacterium isolated from a lactic acid beverage
}

Correspondence

Akira Hiraishi

hiraishi@eco.tut.ac.jp

\author{
Kengo Shimomura, ${ }^{1} \dagger$ Shigeo Kaji ${ }^{2}$ and Akira Hiraishi ${ }^{3}$ \\ 'NCIMB Japan Co., Ltd, Shimizunagasaki, Shizuoka-shi, Shizuoka 424-0065, Japan \\ ${ }^{2}$ Yumai Co., Ltd, Kouga-gun, Shiga 529-1835, Japan \\ ${ }^{3}$ Department of Ecological Engineering, Toyohashi University of Technology, Toyohashi \\ 441-8580, Japan
}

The genus Chryseobacterium was created by Vandamme et al. (1994) to accommodate several species formerly classified in the genus Flavobacterium, i.e. Chryseobacterium balustinum, C. gleum, C. indologenes, C. indoltheticum, C. meningosepticum and C. scophthalmum. Six species, Chryseobacterium defluvii (Kämpfer et al., 2003), C. joostei (Hugo et al., 2003), C. miricola (Li et al., 2003), C. daecheongense (Kim et al., 2005a), C. formosense (Young et al., 2005) and C. taichungense (Shen et al., 2005), have been added to the genus recently. However, C. meningosepticum and $C$. miricola have been transferred to the novel genus Elizabethkingia (Kim et al., 2005b) and the genus now consists of 10 species. 'Chryseobacterium proteolyticum' (Yamaguchi \& Yokoe, 2000) is a member of the genus, although the name has not been validly published. From a lactic acid beverage, we isolated a bacterial strain that is phylogenetically and phenotypically similar to Chryseobacterium species. In this paper, we report the characteristics

Published online ahead of print on 20 May 2005 as DOI 10.1099/ ijs.0.63690-0.

tPresent address: Graduate School of Fisheries Science, Hokkaido University, 3-1-1 Minato-cho, Hakodate 041-8611, Japan.

The GenBank/EMBL/DDBJ accession number for the 16S rRNA gene sequence of strain GUM-Kaji ${ }^{\top}$ is AB193101.

A scanning electron micrograph of cells of strain GUM-Kaji is available as a supplementary figure in IJSEM Online. of the novel bacterium and propose to classify it as a novel species of the genus Chryseobacterium.

The novel bacterium, designated strain GUM-Kaji ${ }^{\mathrm{T}}$ (NCIMB Japan Culture Collection number BAMY $1001^{\mathrm{T}}$ ), was isolated from a fresh lactic acid beverage (Yumai Co., Ltd, Kouga-gun, Shiga Prefecture, Japan) by the agarplating method using nutrient agar (CM3; Oxoid). This bacterium has been considered as a part of the normal community in the lactic acid beverage. For testing, precultures were grown aerobically on the same medium. All test media were incubated at $30^{\circ} \mathrm{C}$ unless otherwise specified. General cell morphology was studied using phase-contrast and light microscopy (BX50F4; Olympus). Morphological observations under a scanning electron microscope were performed at Hanaichi UltraStructure Research Institute (Okazaki, Japan). The Gram reaction was determined using a Favour G Gram-stain kit (Nissui) according to the manufacturer's instructions. A flexirubintype pigment was detected by using the method of Reichenbach (1989). Catalase activity, oxidase activity, the oxidation-fermentation reaction, growth on MacConkey agar and the alkaline reaction on Christensen's citrate were determined by using standard methods (Barrow \& Feltham, 1993). Additional physiological and biochemical tests were performed using an API 20E kit (bioMérieux) according to the manufacturer's instructions. Fatty acid methyl esters were extracted and prepared by using the 
standard protocol of the Microbial Identification System (MIDI; Microbial ID). Extracts were analysed using a Hewlett Packard model HP6890A gas chromatograph equipped with a flame-ionization detector, according to the manufacturer's instructions. Respiratory quinones were detected by using the HPLC method as described previously (Nishijima et al., 1997). Genomic DNA was extracted and purified using the InstaGene Matrix kit (Bio-Rad). The $\mathrm{G}+\mathrm{C}$ content $(\mathrm{mol} \%)$ of the DNA was determined by using the HPLC method, as described previously (KatayamaFujimura et al., 1984). 16S rRNA gene fragments were PCRamplified and sequenced using the MicroSeq Full Gene 16S rDNA Bacterial Sequencing kit (Applied Biosystems) and an ABI Model 3100 Genetic Analyzer (Applied Biosystems). The 16S rRNA gene sequence determined was compared with those retrieved from the GenBank/EMBL/DDBJ databases. Sequence similarities were calculated and a neighbourjoining evolutionary distance tree (Saitou \& Nei, 1987) was constructed using the programs CLUSTAL X (Thompson et al., 1997) and MEGA2 (Kumar et al., 2001). The topology of the tree was evaluated by using the bootstrap resampling method with 1000 replicates (Felsenstein, 1985).

Strain GUM-Kaji ${ }^{\mathrm{T}}$ comprised straight and slightly curved rods measuring $0.6-0.7 \mu \mathrm{m}$ in width and $1.0-1.5 \mu \mathrm{m}$ in length (a scanning electron micrograph of cells is available as a supplementary figure in IJSEM Online). The cells were Gram-negative and non-motile. Colonies on nutrient agar were deep-yellow and shiny. A flexirubin-type pigment was detected. No growth occurred on MacConkey agar. The strain was an aerobic chemo-organotrophic bacterium with a strictly respiratory type of metabolism. Growth occurred at $5-30{ }^{\circ} \mathrm{C}$ but not at $\geqslant 37^{\circ} \mathrm{C}$ (optimum, $20-30{ }^{\circ} \mathrm{C}$ ). The $\mathrm{pH}$ range for growth was $5-8$. Catalase and oxidase activities were present. Casein, gelatin and starch were hydrolysed. Cells were negative for urease activity and nitrate reduction. Acid was produced from D-fructose and D-glucose. Other physiological and biochemical characteristics are shown in the species description.

Cellular fatty acid analysis showed that $\mathrm{C} 15: 0$ iso was the most abundant component $(39 \cdot 7 \%)$. Considerable proportions of summed feature 4 (2-OH-C15: 0 iso and/or $\mathrm{C} 16: 1 \omega 7 c$ and/or $\mathrm{C} 16: 1 \omega 7 t)$ and $\mathrm{C} 17: 1 \omega 9 c$ iso were also found. 3-OH-C17: 0 iso $(19 \cdot 6 \%)$ was the major component of the 3-hydroxy acids. Analysis of the respiratory quinones revealed that menaquinone MK-6 was the sole quinone.

The 16S rRNA gene sequence of strain GUM-Kaji $\mathrm{T}^{\mathrm{T}}$ determined (1476 bp) was compared with those retrieved from the databases. The sequence of strain GUM-Kaji ${ }^{\mathrm{T}}$ was most similar to that of C. joostei LMG $18212^{\mathrm{T}}(95 \cdot 7 \%)$. The neighbour-joining phylogenetic tree clearly showed that strain GUM-Kaji ${ }^{\mathrm{T}}$ was positioned within the cluster of the genus Chryseobacterium, with C. joostei as its nearest phylogenetic neighbour (Fig. 1). The $\mathrm{G}+\mathrm{C}$ content of the genomic DNA of strain GUM-Kaji ${ }^{\mathrm{T}}$ was $36 \cdot 6 \mathrm{~mol} \%$, the value being similar to that of $C$. joostei.

On the basis of the phylogenetic data, it is clear that strain GUM-Kaji ${ }^{\mathrm{T}}$ should be classified as a member of the genus Chryseobacterium. This phylogenetic assignment is supported unequivocally by the chemotaxonomic profiles, i.e. by the presence of $\mathrm{C} 15: 0$ iso and 3-OH-C17:0 iso as the major fatty acids and MK- 6 as the sole respiratory quinone. However, strain GUM-Kaji ${ }^{\mathrm{T}}$ differs from all of the previously established species of Chryseobacterium in terms of a number of phenotypic characteristics (Table 1). For example, strain GUM-Kaji ${ }^{\mathrm{T}}$ can be differentiated from its closest relative, C. joostei, by negative reactions for growth on MacConkey agar and for acid production from maltose and trehalose. Although genomic DNA-DNA reassociation studies were not performed in this study, the low similarities (below 96\%) of 16S rRNA gene sequences between our strain and any established Chryseobacterium species indicate a distinct position for strain GUM-Kaji ${ }^{\mathrm{T}}$ within the genus, since genomic DNAs of bacterial strains having less than $97 \cdot 0 \%$ sequence similarity will usually not reassociate to more than $60 \%$ hybridization (Stackebrandt \& Goebel, 1994). In fact, Chryseobacterium species sharing 94.9-96.0\% 16S rRNA gene sequence similarities showed only $3 \cdot 0-31 \cdot 0 \%$ DNA-DNA relatedness (Yamaguchi \& Yokoe, 2000). DNA binding values as low as 16 and $23 \%$ were even found between $C$. joostei and the two other

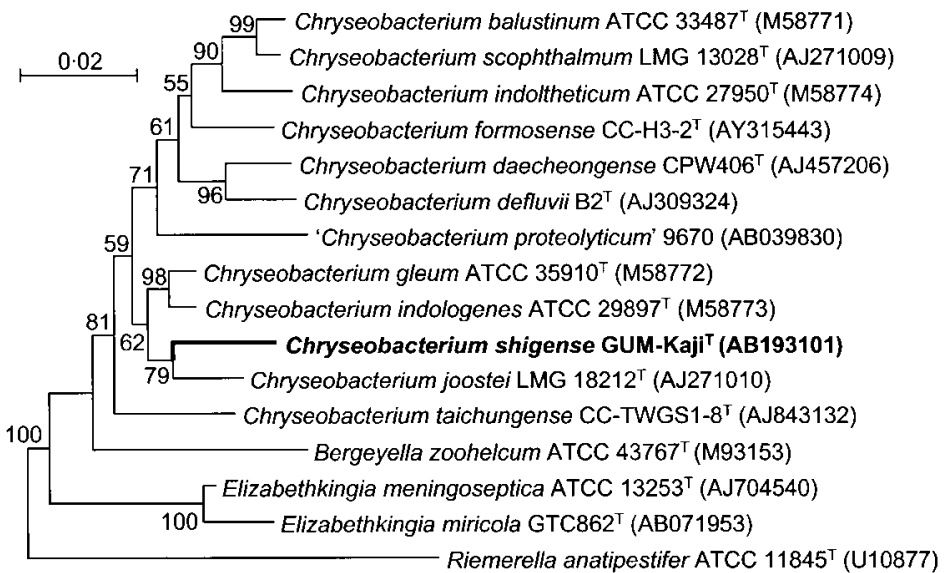

Fig. 1. Neighbour-joining phylogenetic tree, based on 16S rRNA gene sequences, showing the relationships between strain GUM-Kaji ${ }^{\top}$ and previously known species of the genus Chryseobacterium. The database accession numbers for the sequences used in the analysis are given in parentheses. Bootstrap percentages (based on 1000 replicates) are given at the branching points. Riemerella anatipestifer ATCC $11845^{\top}$ was used as the outgroup to root the tree. Bar, $2 \%$ nucleotide substitution rate. 
Table 1. Differential characteristics of strain GUM-Kaji and previously described Chryseobacterium species

Taxa: 1, C. joostei; 2, C. balustinum; 3, C. daecheongense; 4, C. defluvii; 5, C. formosense; 6, C. gleum; 7, C. indoltheticum; 8, C. indologenes; 9, C. scophthalmum; 10, C. taichungense; 11, 'C. proteolyticum'; 12, Elizabethkingia meningoseptica; 13, Elizabethkingia miricola. Symbols: + , positive; -, negative; W, weakly positive; V, variable reaction; D, delayed reaction; NA, information not available. Data for reference species are based on information from Hugo et al. (2003), Li et al. (2003), Kim et al. (2005a, b), Young et al. (2005) and Shen et al. (2005).

\begin{tabular}{|c|c|c|c|c|c|c|c|c|c|c|c|c|c|c|}
\hline Characteristic & GUM-Kaji & 1 & 2 & 3 & 4 & 5 & 6 & 7 & 8 & 9 & 10 & 11 & 12 & 13 \\
\hline \multicolumn{15}{|l|}{ Growth on/at: } \\
\hline $5^{\circ} \mathrm{C}$ & + & + & $\mathrm{D}$ & - & - & - & - & + & - & $\mathrm{D}$ & NA & $\mathrm{NA}$ & - & - \\
\hline $37^{\circ} \mathrm{C}$ & - & - & + & + & + & - & + & - & - & - & + & + & + & + \\
\hline \multicolumn{15}{|l|}{ Production of: } \\
\hline Urease & - & $\mathrm{V}$ & - & - & - & - & - & - & - & + & - & - & $\mathrm{D}$ & + \\
\hline Indole & + & + & + & - & + & + & + & + & + & - & $\mathrm{W}$ & + & $\mathrm{D}$ & + \\
\hline Hydrogen sulphide & - & - & - & - & - & - & - & + & - & - & - & $\mathrm{W}$ & - & + \\
\hline Alkaline reaction on Christensen's citrate & - & $\mathrm{V}$ & - & NA & $\mathrm{NA}$ & NA & + & + & - & + & NA & NA & $\mathrm{D}$ & NA \\
\hline Glycerol & - & $\mathrm{V}$ & - & + & + & NA & + & - & $\mathrm{D}$ & - & NA & $\mathrm{W}$ & + & - \\
\hline Lactose & - & - & - & - & - & NA & - & - & - & - & - & - & + & + \\
\hline Maltose & - & + & - & - & + & - & + & + & + & - & + & + & + & + \\
\hline D-Mannitol & - & $\mathrm{V}$ & - & - & - & - & - & - & - & - & - & $\mathrm{W}$ & + & + \\
\hline Trehalose & - & + & - & + & + & + & + & - & + & + & $\mathrm{W}$ & + & + & + \\
\hline D-Xylose & - & - & - & + & - & $\mathrm{W}$ & + & - & - & - & $\mathrm{W}$ & NA & - & - \\
\hline Mean DNA G + C content $(\mathrm{mol} \%)$ & $36 \cdot 6$ & $36 \cdot 8$ & $33 \cdot 1$ & $36 \cdot 6$ & $33 \cdot 8$ & NA & $38 \cdot 0$ & $33 \cdot 8$ & $38 \cdot 5$ & $34 \cdot 2$ & NA & $37 \cdot 1$ & $37 \cdot 0$ & $34 \cdot 6$ \\
\hline
\end{tabular}

Chryseobacterium species with which it shared $97 \cdot 7$ and $97.6 \% 16 \mathrm{~S}$ rRNA gene sequence similarity, respectively (Hugo et al., 2003). In view of these results, it is logical to conclude that strain GUM-Kaji ${ }^{\mathrm{T}}$ should be classified as a novel species of the genus Chryseobacterium, for which we propose the name Chryseobacterium shigense sp. nov. Although only one strain of the novel species is available at this time, it is important to create a novel species because of the strain's unique origin and distinct phylogenetic position within the genus.

\section{Description of Chryseobacterium shigense sp. nov.}

Chryseobacterium shigense (shi.gen'se. N.L. neut. adj. shigense pertaining to Shiga Prefecture in Japan, the geographical area of isolation of the type strain).

Cells are straight or slightly curved rods measuring $0 \cdot 6-$ $0 \cdot 7 \times 1 \cdot 0-1 \cdot 5 \mu \mathrm{m}$. Gram-negative and non-motile. Strictly aerobic and chemo-organotrophic. Colonies on nutrient agar are deep yellow (flexirubin-type pigment) and shiny. No growth occurs on MacConkey agar. Growth occurs at $5-30{ }^{\circ} \mathrm{C}$ (optimum $20-30{ }^{\circ} \mathrm{C}$ ) but not at $37^{\circ} \mathrm{C}$. The pH range for growth is $5-8$. Catalase and oxidase are present.
Indole is produced. Starch, casein and gelatin are hydrolysed. Negative reactions obtained for nitrate reduction, urease activity, hydrogen sulphide production and an alkaline reaction on Christensen's citrate. Acid is produced from D-fructose and D-glucose but not from L-arabinose, D-xylose, glycerol, lactose, maltose, trehalose, D-mannitol or glycerol. The major fatty acids are $\mathrm{C} 15: 0$ iso and 3-OHC17:0 iso. Considerable proportions of summed feature

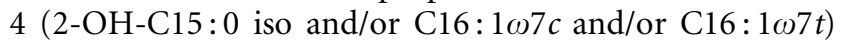
and $\mathrm{C} 17: 1 \omega 9 \mathrm{c}$ iso are also present. Menaquinone MK-6 is the sole respiratory quinone. The $\mathrm{G}+\mathrm{C}$ content of the genomic DNA of the type strain is $36.6 \mathrm{~mol} \%$. The closest phylogenetic relative is $C$. joostei.

The type strain, strain GUM-Kaji ${ }^{\mathrm{T}}\left(=\mathrm{BAMY} 1001^{\mathrm{T}}=\right.$ NCIMB $14047^{\mathrm{T}}=$ DSM $17126^{\mathrm{T}}$ ), was isolated from a lactic acid beverage in Japan.

\section{Acknowledgements}

We are grateful to $M$. Nishijima for helping with the $G+C$ content analysis, N. Tazato for assisting with the morphological and physiological tests, T. Koide for $16 \mathrm{~S}$ rRNA gene sequencing, T. Hisada for quinone analysis and T. Kiyuna for fatty acid analysis. 


\section{References}

Barrow, G. I. \& Feltham, R. K. A. (1993). Cowan and Steel's Manual for the Identification of Medical Bacteria, 3rd edn. Cambridge: Cambridge University Press.

Felsenstein, J. (1985). Confidence limits on phylogenies: an approach using the bootstrap. Evolution 39, 783-791.

Hugo, C. J., Segers, P., Hoste, B., Vancanneyt, M. \& Kersters, K. (2003). Chryseobacterium joostei sp. nov., isolated from the dairy environment. Int J Syst Evol Microbiol 53, 771-777.

Kämpfer, P., Dreyer, U., Neef, A., Dott, W. \& Busse, H.-J. (2003). Chryseobacterium defluvii sp. nov., isolated from wastewater. Int J Syst Evol Microbiol 53, 93-97.

Katayama-Fujimura, Y., Komatsu, Y., Kuraishi, H. \& Kaneko, T. (1984). Estimation of DNA base composition by high performance liquid chromatography of its nuclease P1 hydrolysate. Agric Biol Chem 48, 3169-3172.

Kim, K. K., Bae, H.-S., Schumann, P. \& Lee, S.-T. (2005a). Chryseobacterium daecheongense sp. nov., isolated from freshwater lake sediment. Int J Syst Evol Microbiol 55, 133-138.

Kim, K. K., Kim, M.-K., Lim, J. H., Park, H. Y. \& Lee, S.-T. (2005b). Transfer of Chryseobacterium meningosepticum and Chryseobacterium miricola to Elizabethkingia gen. nov. as Elizabethkingia meningoseptica comb. nov. and Elizabethkingia miricola comb. nov. Int J Syst Evol Microbiol 55, 1287-1293.

Kumar, S., Tamura, K., Jakobsen, I. B. \& Nei, M. (2001). MEGA2: molecular evolutionary genetics analysis software. Bioinformatics $\mathbf{1 7}$, 1244-1245.

Li, Y., Kawamura, Y., Fujiwara, N., Naka, T., Liu, H., Huang, X., Kobayashi, K. \& Ezaki, T. (2003). Chryseobacterium miricola sp. nov., a novel species isolated from condensation water of space station Mir. Syst Appl Microbiol 26, 523-528.
Nishijima, M., Araki-Sakai, M. \& Sano, H. (1997). Identification of isoprenoid quinones by frit-FAB liquid chromatography-mass spectrometry for the chemotaxonomy of microorganisms. J Microbiol Methods 28, 113-122.

Reichenbach, H. (1989). Order I. Cytophagales Leadbetter 1974. In Bergey's Manual of Systematic Bacteriology, vol. 3, pp. 2011-2013. Edited by J. T. Staley, M. P. Bryant, N. Pfennig \& J. G. Holt. Baltimore: Williams \& Wilkins.

Saitou, N. \& Nei, M. (1987). The neighbor-joining method: a new method for reconstructing phylogenetic trees. Mol Biol Evol 4, 406-425.

Shen, F.-T., Kämpfer, P., Young, C.-C., Lai, W.-A. \& Arun, A. B. (2005). Chryseobacterium taichungense sp. nov., isolated from contaminated soil. Int J Syst Evol Microbiol 55, 1301-1304.

Stackebrandt, E. \& Goebel, B. M. (1994). Taxonomic note: a place for DNA-DNA reassociation and 16S RNA sequence analysis in the present species definition in bacteriology. Int J Syst Bacteriol 44, 846-849.

Thompson, J. D., Gibson, T. J., Plewniak, F., Jeanmougin, F. \& Higgins, D. G. (1997). The CLUSTAL_X Windows interface: flexible strategies for multiple sequence alignment aided by quality analysis tools. Nucleic Acids Res 25, 4876-4882.

Vandamme, P., Bernardet, J.-F., Segers, P., Kersters, K. \& Holmes, B. (1994). New perspectives in the classification of the flavobacteria: description of Chryseobacterium gen. nov., Bergeyella gen. nov., and Empedobacter nom. rev. Int J Syst Bacteriol 44, 827-831.

Yamaguchi, S. \& Yokoe, M. (2000). A novel protein-deamidating enzyme from Chryseobacterium proteolyticum sp. nov., a newly isolated bacterium from soil. Appl Environ Microbiol 66, 3337-3343.

Young, C. C., Kämpfer, P., Shen, F. T., Lai, W. A. \& Arun, A. B. (2005). Chryseobacterium formosense sp. nov., isolated from the rhizosphere of Lactuca sativa L. (garden lettuce). Int J Syst Evol Microbiol 55, 423-426. 